\title{
PENGGUNAAN TINGKAT TUTUR BAHASA JAWA SEBAGAI REPRESENTASI RELASI KEKUASAAN
}

\author{
Praptomo Baryadi Isodarus \\ Program Studi Sastra Indonesia, Fakultas Sastra, Universitas Sanata Dharma \\ Surel: praptomo@usd.ac.id
}

\begin{abstract}
ABSTRAK
Tingkat tutur dalam bahasa Jawa yang pada masa sekarang lebih menonjol digunakan sebagai sarana sopan santun berbahasa, jika diteliti sejarah awal perkembangannya, sebenarnya dimanfaatkan untuk merepresentasikan relasi kekuasaan. Artikel ini menyajikan hasil kajian tentang penggunaan tingkat tutur dalam bahasa Jawa sebagai representasi relasi kekuasaan. Ada dua hal yang diteliti, yaitu aspek kebahasaan yang membentuk tingkat tutur dalam bahasa Jawa dan penggunaan tingkat tutur dalam bahasa Jawa untuk merepresentasikan relasi kekuasaan. Untuk menjelaskan dua hal tersebut, penelitian ini dilakukan dengan menggunakan pendekatan Analisis Wacana Kritis (Critical Discourse Analysis). Selain itu, penelitian ini juga dilaksanakan dengan menerapkan metode observasi untuk pengumpulan data, metode distribusional dan metode padan pragmatis untuk analisis data, serta metode informal dan metode formal untuk penyajian hasil analisis data. Ada dua temuan dari penelitian ini. Pertama, yang pokok dari tingkat tutur dalam bahasa Jawa adalah ngoko dan krama. Tingkat tutur ngoko dan krama dibedakan dari kosakatanya sehingga ada kosakata ngoko dan ada kosakata krama. Dalam penggunaannya, tingkat tutur menimbulkan berbagai variasi, yaitu ngoko lugu, antya-basa, basa-antya, wredha krama, kramantara, mudha krama madya krama, madyantara, dan madya ngoko. Temuan kedua adalah penggunaan tingkat tutur dalam bahasa Jawa merepresentasikan relasi kekuasaan penutur dengan mitra tutur. Pada mulanya, pengembangan tingkat tutur memperkuat kedudukan dinasti Mataram sebagai supremasi kekuasaan di Jawa. Pada perkembangan selanjutnya, selain sebagai wujud sopan santun berbahasa, tingkat tutur ngoko dan krama digunakan untuk merepresentasikan relasi kekuasaan personal, yaitu antara penutur dengan mitra tutur. Tuturan ngoko digunakan dalam komunikasi menurun, yaitu komunikasi penutur yang berstatus lebih tinggi kepada mitra tutur yang lebih rendah. Tuturan krama dipakai dalam komunikasi menaik, yaitu komunikasi antara penutur yang berstatus sosial lebih rendah kepada mitra tutur yang berstatus lebih tinggi.
\end{abstract}

Kata Kunci: tingkat tutur, analisis wacana kritis, kekuasaan, bahasa Jawa

\begin{abstract}
The level of speech in Javanese which is more prominent today is used as a means of language courtesy. If we examine the early history of its development, the actual level of speech is used to represent power relations. This article presents the results of a study of the use of speech levels in Javanese as a representation of power relations. There are two things investigated, the linguistic aspects that form the level of speech in Javanese and the use of speech level in Javanese to represent power relations. To explain these two things, this research was conducted using the Critical Discourse Analysis approach. In addition, this research was also carried out by applying observational methods
\end{abstract}


for data collection, distributional methods and pragmatic equivalent methods for data analysis, as well as informal and formal methods for presenting the results of data analysis. There are two findings from this research. First, the main level of speech in Javanese is ngoko and krama. The level of speech of ngoko and krama is distinguished from the vocabulary so that there is a vocabulary of ngoko and there is a vocabulary of krama. In use, speech levels give rise to variations, i.e. ngoko lugu, antyabasa, basa-antya, wredha krama, kramantara, mudha krama madya krama, madyantara, and madya ngoko. The second finding is the use of the speech level in Javanese to represent the relation of the speakers power with the speech partners. Initially, the development of speech levels strengthened the position of the Mataram dynasty as the supremacy of power in Java. In subsequent developments, aside from being a form of language courtesy, the ngoko and krama speech levels are used to represent personal power relations, between the speaker and the speech partner. Ngoko utterances are used in decreased communication, ie communication of higher status speakers to lower speech partners. Krama utterances are used in ascending communication, ie communication between speakers of lower social status to speech partners of higher status.

Keywords: speech level, critical discourse analysis, power, Javanese language

\section{PENDAHULUAN}

Bahasa Jawa merupakan salah satu bahasa daerah dari sekitar 750-an bahasa daerah yang ada di Indonesia. Sampai sekarang bahasa Jawa masih digunakan sebagai sarana komunikasi oleh masyarakat penuturnya yang tinggal di Jawa Tengah, Jawa Timur, Daerah Istimewa Yogyakarta, dan daerah transmigran Jawa di sejumlah wilayah di luar Jawa. Bahasa Jawa masih digunakan dalam berbagai ranah komunikasi, yaitu di dalam keluarga, pergaulan seharihari di masyarakat, pada upacara-upacara tradisional (misalnya upacara kematian, pengantin, dan khitan), dan berbagai pertemuan warga masyarakat Jawa. Selain itu, bahasa Jawa juga masih digunakan dalam komunikasi tulis, seperti surat undangan, karya sastra, dan pada majalah-majalah berbahasa Jawa.

Salah satu ciri yang menonjol dari bahasa Jawa adalah adanya tingkat tutur. Ada perbedaan pendapat di antara para ahli bahasa Jawa mengenai jenis-jenis tingkat tutur dalam bahasa Jawa. Namun, yang paling banyak dikenal oleh umum adalah ngoko dan krama. Sebagaimana dijelaskan oleh Driyarkara (1980: 2-13) bahwa pada zaman dulu (sebelum Mataram) bahasa krama tidak ada. Sejak Kerajaan Mataramlah (permulaan abad ke-17), tingkatan ngoko-krama itu berkembang dan hal ini merupakan proses feodalisasi masyarakat Jawa. Hal ini disebabkan Kerajaan Mataram kehilangan kekuasaan dan orientasi keluar sehingga menjadi "introvert". Proses feodalisasi di Jawa sangat mendalam.

Pendapat tersebut dipertegas oleh Moedjanto (1987: 41-46) bahwa tingkat tutur dalam bahasa Jawa berkembang bersamaan waktunya dengan berkembangnya Kerajaan Mataram. Sebelum Mataram, tingkat tutur bahasa Jawa belum terjadi. Dalam penggunaan bahasa Jawa sebelum Kerajaan Mataram ternyata belum dijumpai bahasa krama.

Menurut Moedjanto (1987: 42-46), dalam masyarakat Jawa penggunaan ngokokrama memiliki empat fungsi, yaitu (i) sebagai sarana pergaulan masyarakat, (ii) sebagai tata unggah-ungguh, (iii) untuk menyatakan rasa hormat, dan (iv) sebagai pengatur jarak sosial (social distance). Dalam konsolidasi kekuasaan, 
di antara keempat fungsi itu, fungsi keempatlah yang terpenting, yaitu sebagai sarana pencipta jarak sosial.

Secara historis, penciptaan dan penggunaan tingkat tutur dalam bahasa Jawa bersifat ideologis. Penggunaan tingkat tutur digunakan untuk merepresentasikan relasi kekuasaan dengan cara menciptakan jarak sosial.

Telah ada sejumlah pustaka yang membahas tingkat tutur bahasa Jawa, yaitu pustaka karya Geertz (1989), Poedjosoedarmo dkk. (1979), Suwadji (1994), Sasangka (1994), dan Harjawiyana dan Supriya (2001). Dalam bukunya yang berjudul Abangan, Santri, Priyayi dalam Masyarakat Jawa yang diterjemahkan dari judul asli The Religion of Java membahas tingkat tutur dalam bahasa Jawa dalam kaitannya dengan etiket atau sopan santun berbahasa. Geertz memaparkan berbagai tingkat tutur dalam bahasa Jawa dan pemakaiannya dalam berbagai tingkat atau status sosial. Geertz juga memberikan contoh penggunaan bahasa Jawa ngoko dan krama dalam berbagai jenis relasi pembicara dan pendengar dengan jarak sosial dan status yang bermacam-macam.

Poedjosoedarmo (1979) dalam bukunya yang berjudul Tingkat Tutur dalam Bahasa Jawa telah meneliti tingkat tutur dalam bahasa Jawa secara lebih luas. Poedjosoedarmo telah menjelaskan berbagai jenis tingkat tutur dalam bahasa Jawa beserta konteks yang mempengaruhi penggunaannya. Dalam buku tersebut menjelaskan sistem tingkat tutur, kosakata penentu tingkat tutur, alih tingkat tutur, interaksi kedaan sosial dengan sistem tingkat tutur, dan daftar leksikoan atau kosakata tingkat tutur.

Suwadji (2013) dalam buku Ngoko lan Krama telah memaparkan senarai kosakata ngoko dan krama dalam bahasa Jawa. Buku ini disusun dengan maksud agar digunakan sebagai pedoman para pemakai bahasa Jawa untuk mencari padanan ngoko-krama. Hal ini disebabkan kosakata krama semakin terkikis penggunaannya di masyarakat, terutama oleh kaum muda.

Sasangka (1994), dalam bukunya yang berjudul Tingkat Tutur Bahasa Jawa Berdasarkan Leksikon Pembentuknya, telah meneliti kosakata ngoko dan krama dalam bahasa Jawa. Dalam buku tersebut telah disajikan penanda morfologis dan penanda bukan morfologis tuturan ngoko dan krama. Dalam buku tersebut juga dipaparkan 13 variasi tingkat tutur ngoko dan krama beserta contoh tuturannya.

Adapun Harjawiyana dan Supriya (2001) telah membuat Kamus Unggah-Ungguh Basa Jawa. Dalam kamus tersebut telah dipaparkan berbagai kata dan penggunaannya dalam ngoko, ngoko alus (ngoko halus), krama, dan krama alus (krama halus) beserta padanannya dalam bahasa Indonesia. Kamus tersebut disusun dengan maksud agar dapat digunakan oleh para pemakai bahasa Jawa sebagai pedoman berbahasa Jawa yang benar dan sopan.

Dari tinjauan pustaka tersebut, tingkat tutur dalam bahasa Jawa telah dibahas dari segi sopan santun berbahasa. Tingkat tutur dalam bahasa Jawa sebagai representasi relasi kekuasaan belum diteliti secara khusus. Oleh sebab itu, penelitian ini memfokuskan kajian pada penggunaan tingkat tutur dalam bahasa Jawa untuk merepresentasikan relasi kekuasaan. Ada dua masalah yang dijawab melalui penelitian ini, yaitu aspek kebahasaan apa saja yang membentuk tingkat tutur dalam bahasa Jawa dan bagaimana tingkat tutur dalam bahasa Jawa merepresentasikan relasi kekuasaan penutur dan mitra tutur.

\section{LANDASAN TEORI}

Pendekatan yang digunakan dalam penelitian ini adalah Analisis Wacana Kritis (Critical Discourse Analyisis). Salah satu 
pandangan penting dari Analisis Wacana Kritis adalah wacana atau penggunaan bahasa bisa bersifat ideologis. Ideologi adalah cara tertentu merepresentasikan dan memproduksi masyarakat dengan mereproduksi relasi kekuasaan yang tidak seimbang, yaitu hubungan dominasi dan eksploitasi (Wodak, 1996: 18; Titscher, 2009: 239).

Sumber kekuasaan itu bersifat hetoregen, seperti kekayaan, status sosial, jabatan formal, organisasi, senjata, jumlah penduduk, dan sebagainya. Jumlah sumber kekuasaan ini makin lama makin bertambah sampai tak ada batasnya (Anderson, 1990: 21). Dengan demikian, individu atau kelompok mendominasi individu atau kelompok yang lain disebabkan individu atau kelompok yang lain menganggap dirinya "lebih" terhadap individu atau kelompok yang lain, yaitu lebih sempurna, lebih kaya, lebih jantan (gender), lebih tua, lebih berpengalaman (senior), lebih pandai, lebih profesional, lebih tinggi jabatannya, lebih besar jumlah anggotanya (mayoritas), atau lebih putih kulitnya (ras) (Baryadi, 2012: 20).

Berdasarkan sumber kekuasaan tersebut, dengan demikian, kekuasaan tidak hanya terkait dengan kekuasaan politik seperti tampak pada dominasi pemerintahrakyat, tetapi juga "kekuasaan personal" (Wareing, 2007: 18), seperti tampak pada dominasi orang biasa-difabel, majikan-buruh, orangtua-anak, suami-istri, dokter-pasien, guru-murid atau dosen-mahasiswa, atasanbawahan, polisi-pesakitan, mayoritasminoritas, orang berkulit putih-orang berkulit hitam, dan sebagainya (Baryadi, 2012: 20).

Representasi kekuasaan berkenaan dengan cara memproduksi atau mereproduksi dominasi dari pihak penguasa ke pihak yang tersubordinasi. Penggunaan bahasa merupakan salah satu modus dominasi. Penggunaan bahasa dapat digunakan oleh pihak dominan untuk mewujudkan dominasinya kepada pihak yang didominasi. Hal ini menyebabkan penggunaan bahasa dapat menjadi tempat bersemayamnya ideologi (location of ideology) (Fairclough, 1989).

Representasi kekuasaan dalam penggunaan bahasa (tanda) sekurangnya berkenaan dengan dua hal, yaitu cara merepresentasikan dan aspek-aspek lingualnya. Mengenai caranya, representasi dapat dilakukan melalui pencerminan atau ikon, konvensi (simbol), dan penjurus (indeks) (Peirce, 1985: 7-23). Adapun aspekaspek bahasa yang dapat dimanfaatkan sebagai sarana untuk merepresentasikan kekuasaan antara lain adalah unsur-unsur bahasa, ragam bahasa, tindak tutur, dan gaya bahasa (Baryadi, 2012: 23-34).

\section{METODE PENELITIAN}

Penelitian ini dilakukan melalui tiga tahap, yaitu pengumpulan data, analisis data, dan penyajian hasil analisis data. Pengumpulan data dilakukan dengan metode simak atau observasi, yaitu menyimak atau mengamati data yang berupa kosakata dan tuturan ngoko dan krama dalam bahasa Jawa. Sumber data kosakata ngoko dan krama adalah buku yang berjudul Tingkat Tutur dalam Bahasa Jawa karya Poedjosoedarmo (1979) buku yang berjudul Ngoko lan Krama karya Suwadji (1994). Selain itu, dalam penelitian ini juga digunakan buku yang berjudul Tingkat Tutur Bahasa Jawa Berdasarkan Leksikon Pembentuknya karya Sasangka (1994) sebagai sumber data tuturan untuk variasi tingkat tutur dalam bahasa Jawa.

Dalam penelitian ini juga dikumpulkan data yang berupa tuturan ngoko dan krama, yaitu dialog pendek yang merepresentasikan relasi kekuasaan penutur dan mitra tutur. Dialog tersebut diperoleh dari dua sumber, yaitu dari tuturan ngoko dan krama yang 
digunakan yang digunakan secara lisan dan dari pembangkitan secara kreatif bahasa Jawa yang peneliti gunakan dalam kehidupan sehari-hari karena peneliti adalah penutur asli bahasa Jawa. Berkenaan dengan sumber pertama, penggunaan bahasa Jawa secara lisan yang digunakan sebagai data adalah percakapan sehari-hari di masyarakat tempat peneliti tinggal dan di lembaga-lembaga pemerintah serta lembaga swasta. Data yang diperoleh melalui pembangkitan secara kreatif bahasa Jawa yang peneliti gunakan, oleh Botha (1981: 67), disebut sebagai data introspeksi.

Setelah

dikumpulkan,

data

diklasifikasikan menurut tingkat tuturnya dan jenis relasi kekuasaan yang direpresentasikan. Data yang sudah dikumpulkan kemudian dianalisis dengan metode agih dan metode padan. Metode agih adalah metode analisis data yang alat penentunya adalah bagian dari bahasa yang bersangkutan itu sendiri (Sudaryanto, 1993: 15). Metode agih dalam penelitian ini diterapkan dengan teknik kontras. Teknik kontras ini digunakan untuk membandingkan tuturan bahasa Jawa Ngoko dan tuturan bahasa Jawa Krama.

Metode padan yang digunakan dalam penelitian ini adalah metode padan pragmatis, yaitu metode padan yang alat penentunya adalah mitra bicara (Sudaryanto, 1993: 15). Dalam analisis data ini tuturan bahasa Jawa Ngoko dan Krama dipadankan dengan jarak sosial pembicara dengan mitra bicara. Metode padan pragmatis ini digunakan untuk membuktikan penggunaan bahasa Jawa Ngoko dan Krama untuk merepresentasikan relasi kekuasaan.

Hasil penelitian ini disajikan dengan menggunakan metode informal dan metode formal. Metode informal adalah metode penyajian hasil analisis data dengan menggunakan kata-kata biasa, yaitu kata-kata yang bersifat denotatif dan bukan kata yang bersifat konotatif (Sudaryanto, 1993: 145). Penyajian formal adalah penyajian hasil analisis data dengan tanda-tanda dan lambang-lambang (Sudaryanto, 1993: 145).

\section{PEMBAHASAN HASIL PENELITIAN}

\subsection{Kosakata Ngoko-Krama dalam Bahasa Jawa}

Sejak Kerajaan Mataram, tuturan ngokokrama berkembang sampai sekarang. Tingkat tutur ngoko-krama dapat dibedakan dengan tegas dari kosakata atau leksikonnya. Kosakata ngoko dapat dirangkai untuk membentuk tuturan ngoko dan kosakata krama dapat dirangkai menjadi tuturan krama (Sasangka, 1991: 58).

Berikut ini disajikan daftar kosakata ngoko dan krama beserta artinya dalam bahasa Indonesia. Daftar kosakata ngoko dan krama ini bersumber dari buku Tingkat Tutur Bahasa Jawa karya Poedjasoedarmo (1979: 69--131). Dalam buku tersebut terdapat tabel kosakata ngoko-krama yang dipilah menjadi standar dan nonstandar, madya, krama inggil, dan krama andhap, serta artinya dalam bahasa Indonesia.

Dalam tabel berikut disajikan kosakata ngoko dan krama. Krama tidak dibedakan menjadi standar dan nonstandar dan juga tidak dibedakan menjadi madya, krama inggil, dan krama andhap. Hal tersebut disebabkan penutur bahasa Jawa pada masa sekarang sudah mengalamai perubahan, yaitu tidak lagi secara tegas membedakan variasi kosakata krama. Penutur bahasa Jawa cenderung hanya mengerti kosakata ngoko dan krama. Selain itu, dalam daftar berikut juga ada perubahan seperlunya. Selain itu, dalam mendaftar kosakata ngoko dan krama juga memperhatikan buku Ngoko lan Krama karya Suwadji (2013) dan Tingkat Tutur Bahasa 
Jawa Berdasarkan Leksikon Pembentuknya karya 87-46) disajikan daftar leksikon madya, Sasangka (1994). Dalam Karya Suwadji (2013: leksikon krama, dan leksikon krama inggil 16-49) disajikan kosakata ngoko dan krama (tinggi) yang disertai artinya dalam bahasa tanpa disertai artinya dalam bahasa Indonesia, tetapi tidak dikontraskan, masingIndonesia. Pada buku karya Sasangka (1994: masing menjadi daftar tersendiri.

\begin{tabular}{|c|c|c|}
\hline Ngoko & Krama & Bahasa Indonesia \\
\hline abang & abrit & merah \\
\hline abot, kabotan & awrat, kawratan & berat, keberatan \\
\hline abur, mabur & iber, miber & terbang \\
\hline adang & bethak & menanak nasi \\
\hline adeg, ngadeg & jumeneng & berdiri \\
\hline adhem, kadhemen & asrep, kasrepen & dingin, kedinginan \\
\hline adhep, madhep, ngadhep, & ajeng, majeng, sowan, ajeng- & hadap, menghadap, \\
\hline adhep-adhepan & ajengan & berhadap-hadapan \\
\hline adhi & rayi & adik \\
\hline $\begin{array}{l}\text { adoh, kadohan, adoh- } \\
\text { adohan }\end{array}$ & tebih, ketebiha, tebih-tebihan & jauh, kejauhan, berjauhan \\
\hline adol, dodolan & sade, sadean & jual, berjualan \\
\hline adu, ngadu & aben, ngaben & adu, mengadu \\
\hline adus & siram & mandi \\
\hline agama & agami & agama \\
\hline age, age-age & engga,enggal-enggal & segera, cepat-cepat \\
\hline aja & ampun & jangan \\
\hline aji, ngaji, ngajeni, pangaji & aos, ngaos, ngaosisi, pangaos & $\begin{array}{l}\text { nilai, menilai, menghargai, } \\
\text { bernilai }\end{array}$ \\
\hline aju, maju, majokke & maju, majeng, ngajengaken & maju, maju, mengajukan \\
\hline ayake & mbokmenawi & barangkali \\
\hline ayo & engga, mangga & mari \\
\hline akeh, kakehan & kathah, kekathahen & banyak, kebanyakan \\
\hline akon & ken, dhawuh & suruh \\
\hline aksama, pangaksama & aksami, pangaksami & ampun, pengampunan \\
\hline aku & kulo, kawula, dalem & aku, saya \\
\hline ngakoni & ngakeni & mengakui \\
\hline ngaku-aku & ngaken-aken & mengaku-aku \\
\hline ala & awon & jelek \\
\hline alang, alangan & pambeng, pambengan & halang, halangan \\
\hline alas & wana & hutan \\
\hline ali-ali & sesupe & cincin \\
\hline alih & pindhah & pindah \\
\hline amarga & mergi & karena \\
\hline amba & wiyar & luas \\
\hline ambu, ngambu & ambet, ngambet & bau, mencium \\
\hline ambung, ngambung & aras, ngaras & cium, mencium \\
\hline
\end{tabular}




\begin{tabular}{|c|c|c|}
\hline ampir, ngampiri & pinarak, nglenggahi & singgah \\
\hline ana, kahanan & wonten, kawontenan & ada, keadaan \\
\hline anak & yoga, lare, putra & anak \\
\hline andel, piandel & pitados, kapitadosan & percaya, kepercayaan \\
\hline anut & tumut, ndherek & turut, ikut \\
\hline angger & uger & asal \\
\hline angon, pangon & angen, pangen & penggembala \\
\hline anyang, nganyang & awis, ngawis & menawar \\
\hline anyar & enggal & baru \\
\hline apa & menapa, punapa & apa \\
\hline apik, becik & sae & bagus \\
\hline apura, ngapura & apunten, ngapunten & maaf, memaafkan \\
\hline aran, ngarani & nami, asma, mastani & nama, menamai \\
\hline arang, arang-arang & awis, awis-awis & jarang, jarang-jarang \\
\hline arep, ngarep-arep & ajeng, ngajeng-ajeng & harap, mengharap \\
\hline asu & segawon & anjing \\
\hline ati & manah & hati \\
\hline awak, ngawaki & selira, nyalirani & badan, melakukan \\
\hline bae & kemawon & saja \\
\hline bacut, kebacut & lajeng, kalajeng & kemudian, telanjur \\
\hline bali, mableni & wangsung, mbangsuli & kembali \\
\hline banget, kebangeten & sanget, kesangeten & sangat, keterlaluan \\
\hline bareng & saereng & bersama \\
\hline banyu & toya & air \\
\hline barep & bajeng & sulung \\
\hline bata & banon & batu bata \\
\hline batin & batos & batin \\
\hline batur & rencang, abdi & pembantu \\
\hline bathuk & palarapan & dahi \\
\hline bebed, bebedan & nyamping, nyampingan & kain panjang untuk pria \\
\hline bebek & kambangan & bebek \\
\hline beda & benten & beda \\
\hline bene, kareben & kajengipun, kersanipun & biar \\
\hline bengi & dalu & malam \\
\hline beras & wos & beras \\
\hline besuk & benjang & besuk \\
\hline becik, kabecikan & sae, kasaenan & baik, kebaikan \\
\hline biyen & riyin & dulu \\
\hline bisa & saged & bisa \\
\hline bojo & semah, garwa & suami/isteri \\
\hline bocah & lare & anak \\
\hline bubar & bibar & usai, selesai \\
\hline bubrah & bibrah & risak \\
\hline bukak & bikak & membuka \\
\hline
\end{tabular}




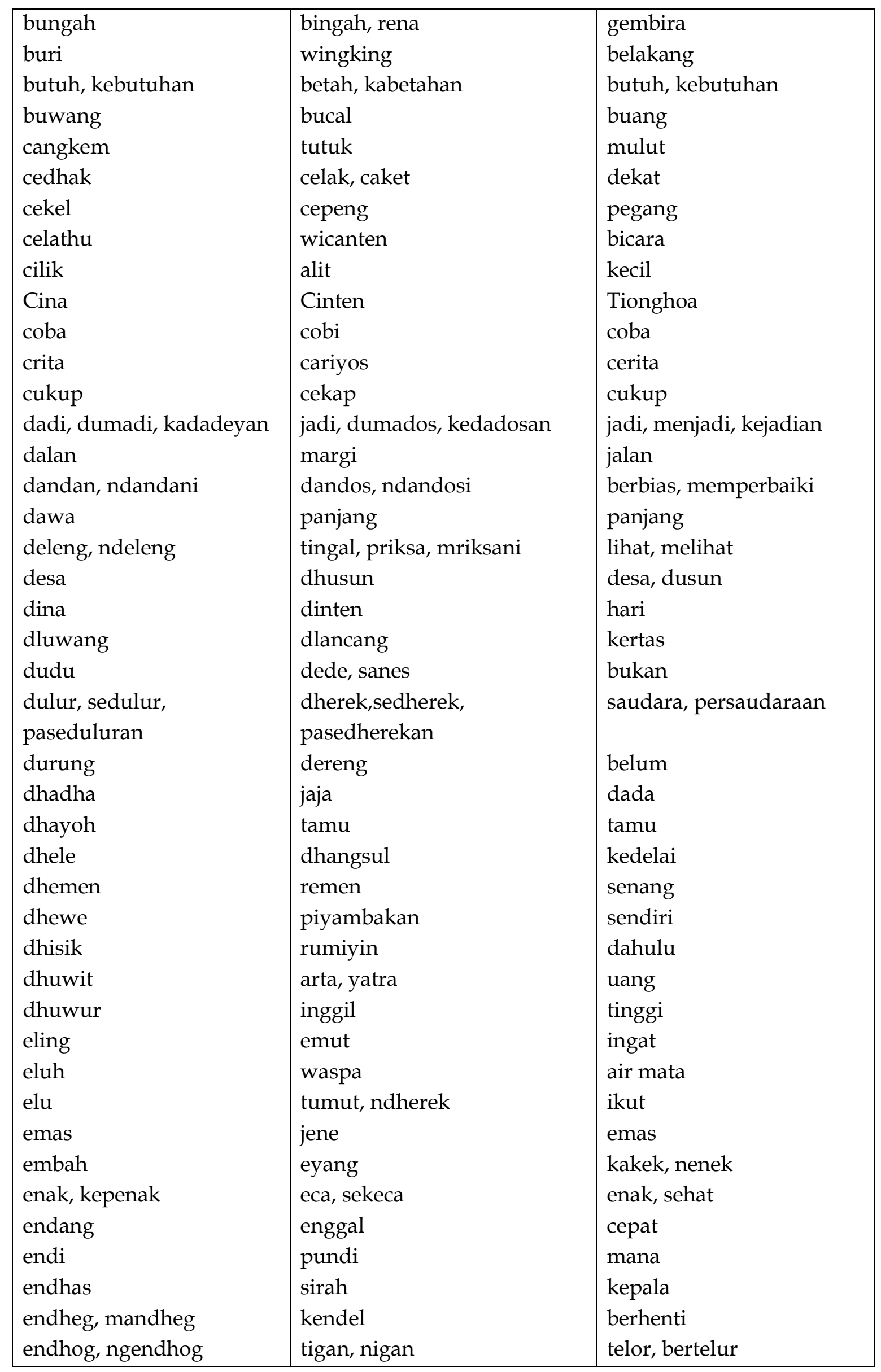




\begin{tabular}{|c|c|c|}
\hline eneng, meneng & kendel & diam \\
\hline enggo, ngenggo & $\begin{array}{l}\text { engge, agem, ngengge, } \\
\text { ngagem }\end{array}$ & memakai \\
\hline entek, ngentekke & telas, nelaske & habis, menghabiskan \\
\hline enggon, panggonan & enggen, panggenan & tempat \\
\hline gamelan & gangsa & gamelan \\
\hline gampang & gampil & mudah \\
\hline ganti, ngganti, gantian & gantos, ngganos, gantosan & $\begin{array}{l}\text { ganti, mengganti, } \\
\text { bergantian }\end{array}$ \\
\hline gawa, nggawa, nggawani & ampil, ngampil, ngampili & $\begin{array}{l}\text { bawa, membawa, berkali- } \\
\text { kali membawa }\end{array}$ \\
\hline gawe, nyambut gawe & damel, nyambut damel & buat, bekerja \\
\hline gedhang & pisang & pisang \\
\hline gedhe & ageng & besar \\
\hline gelem & purun, kersa & mau, bersedia \\
\hline geneya & kening punapa & mengapa \\
\hline genep & jangkep & lengkap \\
\hline genti & gentos & gilir \\
\hline gering & kera & kurus \\
\hline getih & rah & darah \\
\hline godhong & ron & daun \\
\hline golek & pados & mencari \\
\hline goroh & dora & bohong \\
\hline graji & grantos & gergaji \\
\hline gugah & wungu & bangun \\
\hline gugu & gega, ngestokaken dhawuh & taat \\
\hline guyu, ngguyu & gujeng, gumujeng & tawa, tertawa \\
\hline gula & gendhis & gula \\
\hline gulu & jangga & leher \\
\hline guna & gina & guna \\
\hline gunem, guneman & ginem, ngendika, ngendika & berbicara \\
\hline ijo & ijem & hijau \\
\hline ijol, ijolan & liru & tukar, bertukar \\
\hline iya & inggih & iya \\
\hline kae & menika, nika & itu \\
\hline iket & udheng, dhestar & ikat kepala \\
\hline iki & menika & ini \\
\hline $\mathrm{iku}$, kuwi & niku & itu \\
\hline ilang, kelangan & ical, kecalan & hilang, kehilangan \\
\hline inep, nginep & sipeng, nyipeng & menginap \\
\hline ingu, ngingu & ingah, ngingah & memelihara \\
\hline ireng & cemeng & hitam \\
\hline irung & grana & hidung \\
\hline isih & taksih, tesih & masih \\
\hline
\end{tabular}




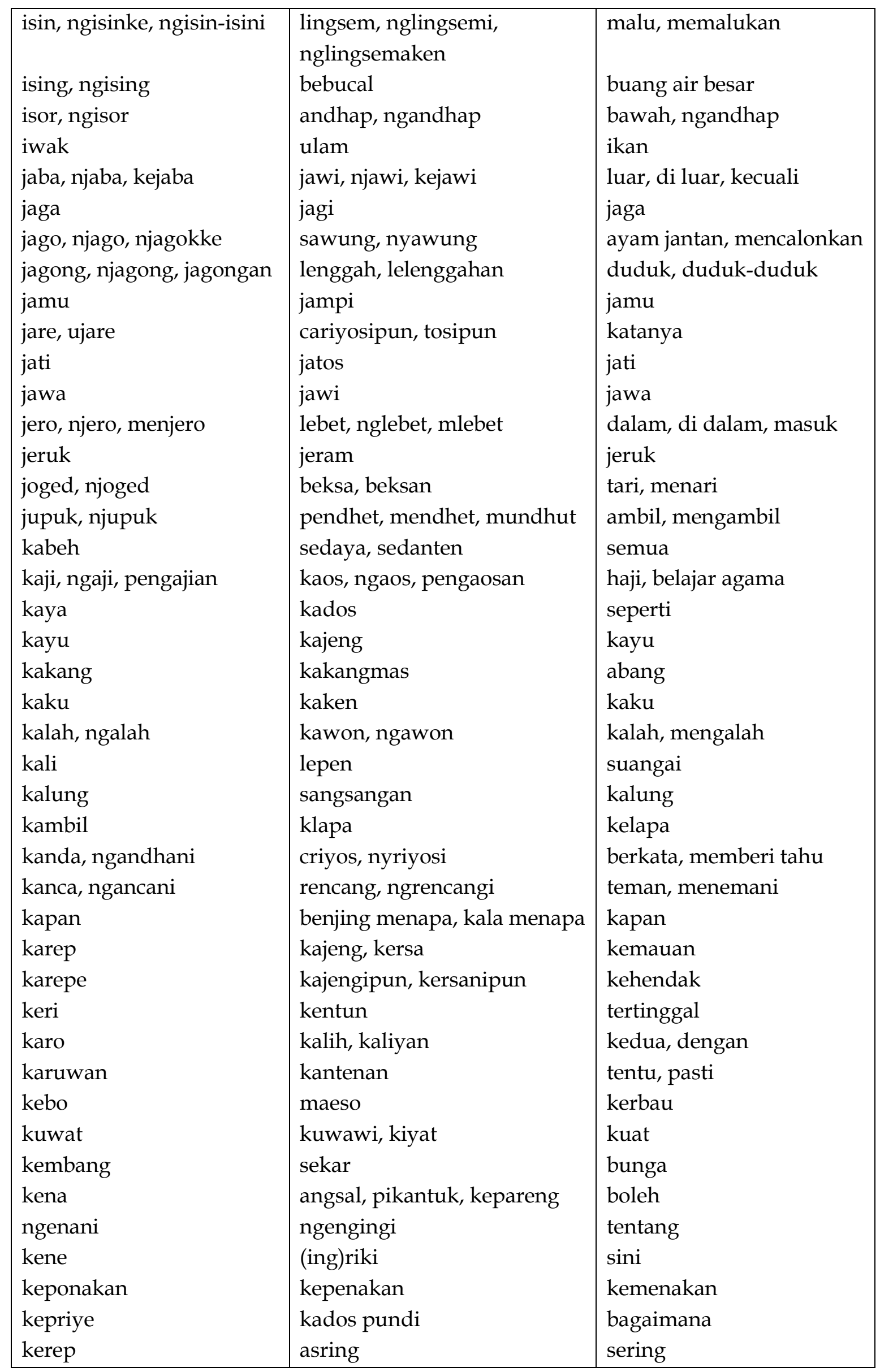




\begin{tabular}{|c|c|c|}
\hline keris & dhuwung & keris \\
\hline kesusu & kesesa & tergesa-gesa \\
\hline ketan & ketos & ketan \\
\hline ketara & ketawis & kentara \\
\hline ketok & ketingal & kelihatan \\
\hline kira, kira-kira & kinten, kinten-kinten & kira, kira-kira \\
\hline kirim, ngirim & kintun, ngintun & kirim, mengirim \\
\hline klambi & rasukan & baju \\
\hline klasa & gelaran & tikar \\
\hline kleru & klentu & keliru \\
\hline klumpuk, nglumpuk, & klempak, nglempak, & kumpul, mengumpul, \\
\hline klumpukan & nglempakan & kumpulan \\
\hline kon/akon & ken/aken, dhawuh & suruh \\
\hline kono & ngriku & situ \\
\hline kowe & sampeyan, panjenengan & kamu \\
\hline kramas, ngramasi & jamas, njamasi & keramas, mengeraasi \\
\hline krasa & kraos & terasa \\
\hline krasan & kraos & kerasan \\
\hline kringet & riwe & keringat \\
\hline kubur, kuburan, ngubur & makam, sareyan, nyarekaken & kuburan, mengubur \\
\hline kudu & kedah & harus \\
\hline kukuh & kekah & kuat \\
\hline kulak, kulakan & kilak, kilakan & kulak, kulakan \\
\hline kulina & kulinten & biasa \\
\hline kulon, ngulon & kilen, ngilen & barat, ke barat \\
\hline kumat & kimat & kambuh \\
\hline kumpul, pakumpulan & kempal, pakempalan & kumpul, perkumpulan \\
\hline kuna, kuna makuna & kina, kina makina & kuna, sejak dulu kala \\
\hline kuning & jene & kuning \\
\hline kurang, ngurangi & kirang, ngirangi & kurang, mengurangi \\
\hline kuru & kera, susut & kurus \\
\hline kurung, kurungan & sengker, sengkeran & kurung, kurungan \\
\hline kutha & kitha & kota \\
\hline kuwasa & kuwaos & kuasa \\
\hline kuwat & kiyat & kuat \\
\hline kuwatir & kuwator & kawatir \\
\hline kuwawa & kuwawi & kuat \\
\hline labuh,nglabuhi & labet, nglabeti & berjasa untuk \\
\hline ladi, laden, leladi & lados, lelados & layani, melayani \\
\hline lagi & saweg & sedang \\
\hline lair & miyos & lahir \\
\hline layang & serat & surat \\
\hline laki & semah, garwa & suami \\
\hline laku & lampah, tindak & jalan \\
\hline
\end{tabular}




\begin{tabular}{|c|c|c|}
\hline lelakon, lakon & kelampahan, lelampahan & terjadi \\
\hline mlaku, mlaku-mlaku & mlampah, mlampah- & berjalan, berjalan-jalan \\
\hline nglakoni & mlampah & puasa, menjalani \\
\hline lelaku & nglampahi & berpergian, sekarat \\
\hline lali, kelalen, lalen & lelampah, tindakan & lupa, kelupaan, pelupa \\
\hline lambe & supe, kesupen, supenan & bibir \\
\hline lanang, lanangan, & lathi & lelaki, jantan, alat kelamin \\
\hline pelanangan & jaler, kakung, jaleran, & laki-laki \\
\hline Landa & pejaleran & Belanda \\
\hline lara & landi & sakit \\
\hline larang & sakit & mahal \\
\hline lawang & awis & pintu \\
\hline lawas & konten & lama \\
\hline lawe, selawe & lami & dua puluh lima \\
\hline lawon & langkung, selangkung & mori \\
\hline lebu, mlebu, lebon, & pethakan & dalam, masuk, ongkos \\
\hline kelebu, kelebon & $\begin{array}{l}\text { lebet, mlebet, lebetan, } \\
\text { kelebet, kelebetan }\end{array}$ & $\begin{array}{l}\text { pembuatan, termasuk, } \\
\text { kemasukan }\end{array}$ \\
\hline lek, melek, lek-lekan & wungu, wungon & bangun, terjaga, berjaga \\
\hline lemah, palemahan & siti, pasiten & bidang tanah \\
\hline lemu & lema & gemuk, subur \\
\hline leren & kendel & istirahat \\
\hline liya & sanes & lain \\
\hline lima & gangsal & lima \\
\hline liwat, keliwar & langkung, miyos, kelangkung & lewat, kelewat \\
\hline lor, ngalor & ler, ngaler & utara, ke utara \\
\hline loro, keloron & kalih, kekalih & berdua \\
\hline lulang & cucal & kulit \\
\hline lumrah & limrah & biasa, kebiasaan \\
\hline lunga, leluangan & kesah, tindakan & pergi, bepergian \\
\hline lungguh, kalungguhan & linggih, kalinggihan & duduk, kedudukan \\
\hline luput, kaluputan & lepat, kalepatan & salah, kesalahan \\
\hline luwih, linuwih, keluwihan & $\begin{array}{l}\text { langkung, linangkung, } \\
\text { kelangkungan }\end{array}$ & lebih, luar biasa, kelebihan \\
\hline maling & pandung & pencuri \\
\hline maneh & malih & lagi \\
\hline manuk & peksi & burung \\
\hline mangkana, mangkene & makaten & demikian \\
\hline mara & dateng & datang \\
\hline mari & mantun & sembuh \\
\hline mata & mripat, paningal & mata \\
\hline mati & pejah, tilar donya, seda & mati \\
\hline mau & wau & tadi \\
\hline mawa & mawi & dengan \\
\hline
\end{tabular}




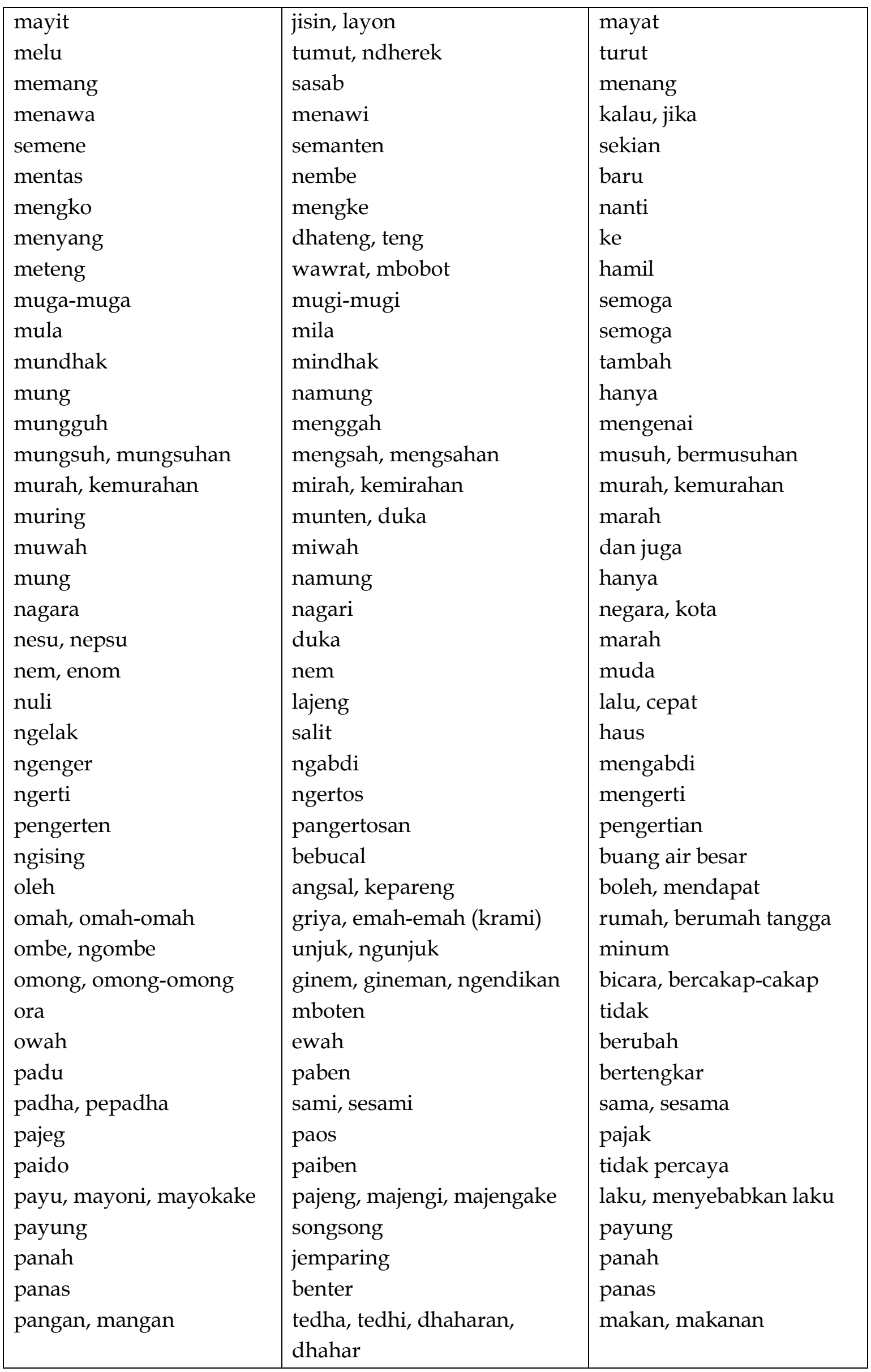




\begin{tabular}{|c|c|c|}
\hline pari & pantun & padi \\
\hline pasa & siyam & puasa \\
\hline pasar & peken & pasar \\
\hline pekarangan & pekawis & pekarangan \\
\hline pijet & petek & pijat \\
\hline pikir & manah, penggalih & pikir \\
\hline pira & pinten & berapa \\
\hline piranti & pirantos & alat \\
\hline pisan & pisan, pindhah & sekaligus \\
\hline pitik & ayam & ayam \\
\hline percaya & pitados & percaya \\
\hline prayoga & prayogi & seyogyanya \\
\hline prau & perahu & baita \\
\hline prakara & prekawis & perkara \\
\hline prihatin & prihatos & prihatin \\
\hline priyayi & priyantun & priyayi \\
\hline puluh, sepuluh & dasa, sedasa & puluh, sepuluh \\
\hline putih & pethak & putih \\
\hline putu & wayah & cucu \\
\hline pasa & siyam & puasa \\
\hline rai & pasuryan & wajah \\
\hline rasa & raos & rasa \\
\hline rata & radin & rata \\
\hline rebut & rebat & rebut \\
\hline rega & regi & harga \\
\hline rekasa & rekaos & sukar \\
\hline rembug & rembag & berunding \\
\hline rembulan & cadra & bulan \\
\hline rene, mrene & mriki & ke sini \\
\hline rewang & rencang & membantu \\
\hline ribut & ribet & ribut \\
\hline riyaya & riyadi & hari raya \\
\hline rono, mrono & mriku & pergi ke sana \\
\hline rumat & rimat & simpan, pelihara \\
\hline rungu, krungu & pireng, mireng & dengar, mendengar \\
\hline rupa & rupi & rupa \\
\hline rusak & risak & rusak \\
\hline rusuh, ngrusuhi & resah, ngresahi & rusuh, mengganggu \\
\hline saguh & sagah & sanggup \\
\hline saka & saking & dari \\
\hline saiki & sakniki & sekarang \\
\hline salin & santun, gantos & ganti pakaian \\
\hline sambung, sesambungan & sambet, sesambetan & sambung, hubungan \\
\hline samubarang & samukawis & segala sesuatu \\
\hline
\end{tabular}




\begin{tabular}{|c|c|c|}
\hline sangga & sanggi & sangga \\
\hline sapa & sinten & siapa \\
\hline sapi & lembu & sapi \\
\hline sarwa & sarwi & serba \\
\hline sasi & wulan & bulan \\
\hline sawah & sabin & sawah \\
\hline sebut & sebat & sebut \\
\hline sedhela & sekedhap & sebentar \\
\hline sedheng & cekap & cukup \\
\hline seje & sanes, benten & lain \\
\hline sega & sekul & nasi \\
\hline segara & seganten & laut \\
\hline seka & saking & dari \\
\hline semaya & semados & menangguhkan \\
\hline semana & semanten & sekian itu \\
\hline semene & semanten & sekian \\
\hline semono & semonten & sebesar itu \\
\hline seneng, nyenengke & remen, ngremenaken & senang, menyenangkan \\
\hline separo & sepalih & setengah \\
\hline sepi & sepen & sepi \\
\hline seprana-seprene & seprika-spriki & $\begin{array}{l}\text { sejak dulu hingga } \\
\text { sekarang }\end{array}$ \\
\hline sero & sora & keras \\
\hline sesuk & benjang & esok \\
\hline sethithik & sekedhik & sedikit \\
\hline sida & siyos & jadi, sesuai \\
\hline siji & setunggal & satu \\
\hline sikil & suku, sampeyan & kaki \\
\hline silih, nyilih & sambut, nyambut, ngampil & meminjam \\
\hline silihan & sambutan & pinjaman \\
\hline sing & ingkang & yang \\
\hline slamet & wilujeng, sugeng & selamat \\
\hline sok & sering & kadang-kadang \\
\hline sok uga & sok ugi & asal \\
\hline sore & sonten & sore \\
\hline sranta & srantos & sabar \\
\hline suwara & suwanten & suara \\
\hline suwe & dangu & lama \\
\hline suweng & sengkang & subang \\
\hline tak & kulo & saya \\
\hline takon & tanglet & tanya \\
\hline tali & tangsul & tali \\
\hline tamba & jampi & obat \\
\hline tampa, nampa & tampi, nampi & terima, menerima \\
\hline
\end{tabular}




\begin{tabular}{|c|c|c|}
\hline tandur, nandur & tanem, nanem & tanam, menanam \\
\hline tangan & asta & tangan \\
\hline srengenge & surya & matahari \\
\hline suguh & segah, sugata & jamu \\
\hline suket & rumput & rumput \\
\hline sumurup & sumerep, priksa & tahu \\
\hline supaya & supados & supaya \\
\hline surasa & suraos & $\operatorname{arti}$ \\
\hline suruh & sedhah & sirih \\
\hline surup & serap & petang \\
\hline susah & sisah & susaha \\
\hline tangga & tanggi & tetangga \\
\hline tanggung & tanggel & tanggung \\
\hline tangi & wungu & bangun \\
\hline tangis & muwun & menagis \\
\hline tapih & nyamping & kain wanita \\
\hline tari & taros & tanya, tawar \\
\hline tau & nate & pernah \\
\hline teka & dhateng, rawuh & datang \\
\hline tekan & dumugi & sampai \\
\hline telu & tiga & tiga \\
\hline tembang & sekar & lagu, nyanyi \\
\hline tenan & saestu, estu, yektos & sungguh \\
\hline temu & panggih & bertemu \\
\hline tepung & tepang & kenal \\
\hline terus & teras, lajeng & teras \\
\hline tiba & dhawah & jauh \\
\hline tilik & truwi & berkunjung, menengok \\
\hline tinggal & tilar & tinggal \\
\hline tlaten & tlatos & telaten \\
\hline tonton, nonton & tingal, priksa, ningali & lihat, melihat \\
\hline tuku & tumbas & membeli \\
\hline tulis & serat & surat, tulis \\
\hline tunggang, nunggang & titih, nitih & naik \\
\hline tunggangan & titihan & kendaraan \\
\hline tunggu & tengga & tunggu \\
\hline turu & tilem, sare & tidur \\
\hline turun & tedhak & turun \\
\hline tutur & sanjang, caos/paring priksa & berkata \\
\hline tuwa & sepuh & tua \\
\hline udan & jawah & hujan \\
\hline udhun, mudhun & tedhak & turun \\
\hline uga & ugi & juga \\
\hline uyah & sarem & garam \\
\hline
\end{tabular}




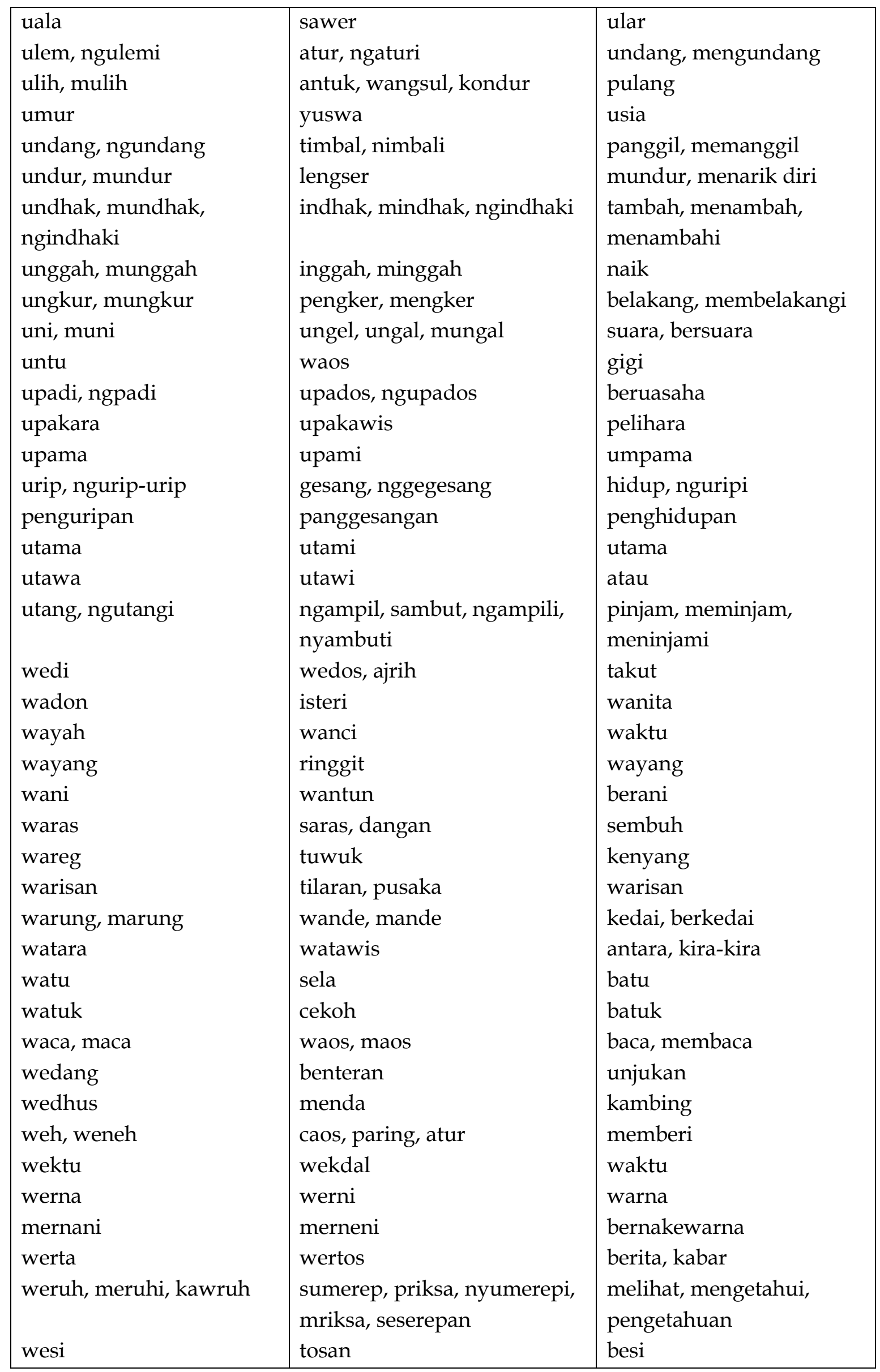




\begin{tabular}{|l|l|l|}
\hline wetara, sawetara & wetawis, sawetawis & kira-kira \\
weteng, meteng & padharan, nggarbini & perut, hamil \\
wetu, metu & wedal, medal & keluar \\
wilang, milang & wical, mical & hitung, menghitung \\
wis (uwis) & sampun & sudah \\
wicara & wicanten & bicara \\
wiwit & milai & mulai \\
wong & tiyang & orang \\
wulang, mulang, & wucal, mucal, wucalan & ajar, mengajar, pengajaran \\
wulangan & & \\
wuri, mburi & wingking & belakang \\
ya, iya & nggih, inggih & ya \\
yekti, sayekti & yektos, sayektos & betul, sebetulnya \\
\hline
\end{tabular}

\subsection{Variasi Ngoko-Krama dalam Bahasa Jawa}

Sasangka (1991: 58 dan 1994: 38) menyatakan bahwa tingkat tutur bahasa Jawa-yang secara jelas dapat dibedakan pada prinsipnya hanya ada dua macam, yaitu (a) tingkat tutur yang berbentuk ngoko dan (b) tingkat tutur yang berbentuk krama. Kemudian di antara dua tataran pokok itu terdapat banyak variasi. Dijelaskan oleh Moedjanto (1987: 60) bahwa tingkat tutur dalam bahasa Jawa sangatlah rumit meskipun tataran yang pokok sebenarnya hanya dua, yaitu ngoko dan krama.

Poedjasoedarmo (1979: 19-23) dan Suwadji (2013: 10-14) membagi tingkat tutur bahasa Jawa menjadi bahasa ngoko, bahasa madya, dan bahasa krama. Kemudian bahasa ngoko dibagi lagi menjadi ngoko lugu, ngoko antya-basa, dan ngoko basa-antya.

Bahasa ngoko ditandai dengan penggunaan kosakata ngoko dan imbuhan di-, -(n)e, dan -(k)ake. Kemudian ngoko lugu merupakan bahasa ngoko yang terdiri atas semua kosakata ngoko dan imbuhan ngoko. Ngoko antya-basa ditandai dengan penggunaan kosa kota ngoko yang dicampuri krama dan penggunaan imbuhan ngoko. Ngoko basa-antya terdiri atas kosakata ngoko dan krama serta imbuhan ngoko.

Bahasa krama memiliki variasi wredha krama, kramantara, dan mudha krama. Bahasa krama ditandai dengan kosakata krama dan imbuhan krama, yaitu dipun-, -(n)ipun, dan (k)aken. Wreda krama lazim digunakan untuk berkomunikasi antara orang muda (wreda) kepada orang muda. Dalam wreda-krama digunakan kosakata krama dan imbuhan ngoko. Kramantara digunakan dalam komunikasi antara penutur dan mitra tutur yang status sosialnya sama (jabatan, pangkat, pendidikan, usia). Kramantara ditandai dengan penggunaan kosakata dan imbuhan krama. Mudha krama biasanya digunakan untuk berkomunikasi antara orang muda (mudha) dengan orang tua. Mudha krama ditandai dengan penggunaan kosakata krama (inggil) dan imbuhan krama.

Bahasa madya merupakan variasi tingkat tutur yang berada di antara ngoko dan krama. Bahasa madya memiliki variasi madya krama, madyantara, dan madya ngoko. Madya ngoko ditandai dengan pemakaian kosakata krama dan kosakata ngoko serta imbuhan ngoko. Madyantara merupakan variasi tingkat tutur bahasa Jawa yang ditandai dengan pemakaian kosakata kormo dan imbuhan ngoko. Madya krama adalah variasi tingkat 
tutur bahasa Jawa yang ditandai penggunaan kosakata krama (inggil) dan imbuhan ngoko.

Sasangka (1994:1 -3) mengemukakan 13 jenis variasi tingkat tutur dalam bahasa Jawa, yaitu ngoko lugu, ngoko antyabasa, ngoko basaantya, madyangoko, madyantara, madya krama, krama ndesa, krama inggil, basa kedhaton, dan basa kasar. Setiap jenis variasi tingkat tutur diberi contoh tuturannya.

\subsection{Sejarah Timbulnya Tingkat Tutur dalam Bahasa Jawa}

Sejak awal perkembangannya, tingkat tutur dalam bahasa Jawa digunakan untuk merepresentasikan kekuasaan. Hal ini diuraikan dalam buku Konsep Kekuasaan Jawa: Penerapannya oleh Raja-Raja Mataram yang ditulis oleh Moedjanto (1987: 41-75). Buku inilah yang digunakan sebagai sumber sejarah perkembangan tingkat tutur dalam bahasa Jawa dalam penelitian ini.

Dalam buku tersebut dijelaskan bahwa awal pengembangan tingkat tutur dalam bahasa Jawa tidak dapat dilepaskan dari konsulidasi kedudukan dinasti Mataram. Dinasti Mataram merupakan dinasti orang kebanyakan dan bukan dari keturunan raja sebagaimana yang lazim terjadi pada penguasa kerajaan di Jawa. Dinasti Mataram berasal dari golongan petani. Karena perjuangaannyalah, dinasti ini mengubah statusnya dari kelas yang diperintah menjadi kelas yang memerintah. Pada zaman kesultanan Pajang, dinasti Mataram telah berhasil mengubah dirinya sampai ke taraf penguasa kadipaten atau kabupaten, setaraf dengan penguasa kabupaten lain seperti Jipang, Madiun, Surabaya, dan Madura. Keempat kabupaten ini, bersama dengan banyak kabupaten lain merupakan bawahan Sultan Pajang. Jadi, bupatinya tunduk kepada Sultan Pajang sebagai pemegang supremasi (kekuasaan tertinggi) di Jawa (Moedjanto, 1987: 41).

Setelah Pajang mengalami masa surut, Mataram dapat mengubah dirinya menjadi kerajaan, yang memegang kekuasaan tertinggi di Jawa. Mataram membawahkan berbagai kabupaten yang semula bawahan kesultanan Pajang. Setelah Mataram berhasil mengubah statusnya dari kabupaten ke kerajaan, berbagai upaya dilakukan untuk mengukuhkan kedudukannnya yang baru sebagai pemegang supremasi di Jawa. Upaya itu ada yang bercorak politik dan militer, ada yang bercorak mitis dan magis-religius, ada yang bercorak kultural. Di antara upaya konsolidasi yang bercorak kultural terdapat beberapa pengembangan sastra babad dan pengembangan bahasa Jawa dengan tatarannya ngoko-krama (tingkat rendah atau kasar dan tingkat tinggi atau halus). Sastra babad dikembangkan oleh dinasti Mataram sebagai alat pembangunan politik (Moedjanto, 1987: 41).

Dijelaskan oleh Moedjanto (1987: 42), bahwa tingkat tutur ngoko-krama dalam masyarakat Jawa memiliki empat fungsi, yaitu (i) sebagai norma pergaulan masyarakat, (ii) sebagai tata unggah-ungguh, (iii) untuk menyatakan rasa hormat dan keakraban, (iv) dan sebagai pengatur jarak sosial (social distance). Dalam kaitannya dengan pengembangan kekuasaan yang menyangkut juga masalah konsolidasi kedudukan, fungsi keempatlah, yaitu sebagai pengatur jarak sosial yang penting.

Setelah dinasti Mataram berhasil merebut supremasi kekuasaan di Jawa, dinasti itu perlu memperkuat kedudukannya yang baru direbut. Pengembangan tataran ngokokrama adalah salah satu jalan untuk memperkokoh kedudukan dinasti Mataram sebagai dinasti di Jawa. Jadi, tataran ngokokrama memang sengaja dikembangkan sehingga menjadi rumit, sebagai alat politik, 
justru karena dinasti Mataram menyadari dirinya berasal dari kalangan petani. Untuk menopang kedudukan sosial yang baru, jarak sosial antara dinasti Mataram dengan kelompok sosial yang lain perlu diciptakan. Salah satu alat untuk terciptanya jarak sosial itu ialah pengembangan tataran ngoko-krama; tataran krama merupakan tataran atas, tataran ngoko merupakan tataran bawah.

Tataran ngoko-krama muncul pada zaman Mataram. Pada zaman pra-Mataram belum ada krama. Hal ini dibuktikan oleh Moedjanto (1987: 46-49) bahwa bahasa Jawa Kuna dan bahasa Jawa Tengahan belum mengenal tingkatan ngoko dan kormo. Pada abad XIV, XV, dan XVI tataran ngoko-krama belum terbentuk. Barulah sesudah tahun 1600, bersamaan kerajaan Mataram, tataran ngokokormo terbentuk dan digunakan dalam percakapan.

Berikut ini ditunjukkan kutipan dari prasasti Sultan Agung yang menurut Brandes (1889: 339-362) dikeluarkan pada tahun 1632 (dalam Moedjanto, 1987: 53).

"Penget. Kang surat piyagem saking isun sultan Mataram, kagadhuh dening si Wanda, wadana Surakarta ka(ng) satja marang isun, lahiring surat piyagem: si Wanda sun pradikaken sarta wewe(ng)kone. Mandala Tjipinaha-Bodjongeren, $i k u$ kang kawerat, dening si Wanda iku adja ana kang nganisiku, disakerepe, angulon watas Banten ngalor ing Tjarebon, pitung pa(n)djenengan adja temu marangisun. Ana dene tingkahe si $W a(n) d a$ milu nganglakoning gaweng lurug maring Ukur (anglakoni gawe anglurug maring Ukur) $i k u$ pun sedhahi Prajangan kalih welas sarta sun djenengaken mantri. Ana dene patut si Wanda iku kakange Wirawangsa kang djeneng ta (u) menggung Wiradada nata Prajangan, wadana kalih welas. Titi ing surat piyagem, kala nurat dina Senen tanggal ping sanga sasi Mukaram tahun Djimakir."

Pada kutipan tersebut baru terdapat beberapa kata krama, misalnya piyagem, pradikaken, pa(n)djenengan, kalih welas.

Berikut ini dikutipkan dari prasasti yang menurut Brandes berasal dari sekitar tahun 1680, yaitu pada zaman Amangkurat II (dalam Moedjanto, 1987: 54).

"Penget! Ingkang serat piagem kangjeng kyahi i ngabehi-(ingabehi) Raksapraja ing Dayehluhur, kagaduha dening paman Wargajaya; milane manira gaduhi surat sakehane wong Dayehluhur kang wenten Prayangan, paman Wargajaya kang manira piyadeg dadiya babone wong Dayehluhur kang wenten kilen, nanging suka manira wentena kang ageng drapratowin. Titi. Kala nulis dina Sabtu tanggal ping nem sasi Rabiyulakir tahun Wawu."

Dalam kutipan tersebut juga baru terdapat beberapa kata krama, misalnya serat, piagem, kangjeng, milane, wenten, kilen, dan ageng.

Berikut ini dikemukakan percakapan antara Ki Ageng Sela dengan Raden Jaka Tingkir. Percakapan sudah menggunakan tuturan ngoko-krama. Ki Ageng Sela menggunakan tuturan ngoko, sedangkan Raden Jaka Tingkir menggunakan tuturan krama. Percakapan berikut dikutip dari Babad Tanah Djawi (dalam J.H. Menisma 1941: 67) yang dikutip juga oleh Moedjanto (1987: 63).

Selasa : "Tole, saelingmu kowe bijen wis ngimpi apa?"

Tingkir : "Kala koela tirakat dateng ing redi Tela-Maja roemijin, wonten ing rikoe koela ing daloe tilem sarta soepena katiban remboelan. Sanalika oegi redi ing Tela-mja moengel goemledoeg. Koela ladjeng tangi. Poenika kados poendi ing wahannipoen?" 
Pada dialong tersebut diketahui bahwa $\mathrm{Ki}$ Ageng Sela menggunakan tuturan ngoko dan Jaka Tingkir memakai tuturan krama. Moedjanto (1987: 67) mengemukakan kemungkinan hubungan kedua tokoh tersebut adalah (i) Jaka Tingkir lebih muda dari segi hubungan kekerabatan, (ii) Jaka Tingkir lebih muda usianya, (iii) Jaka Tingkir lebih rendah tingkat kebangsawanannya, (iv) Status Jaka Tingkir dalam pemerintahan lebih rendah, dan (v) prestise Sela sangat tinggi.

Dari kutipan percakapan antara $\mathrm{Ki}$ Ageng Sela dan Jaka Tingkir tersebut, tampak bahwa pada abad XVII tuturan ngoko-krama sudah berkembang. Tuturan ngoko-krama sejak awal perkembangannya sudah terkait dengan hubungan kekuasaan antara penutur dan mitra tutur. Penutur yang memiliki kekuasaan yang lebih tinggi cenderung menggunakan tuturan ngoko kepada mitra tutur yang status sosialnya lebih rendah, sedangkan penutur yang status sosialnya lebih rendah menggunakan tuturan krama kepada mitra tutur yang kekuasaannya lebih tinggi.

\subsection{Tingkat Tutur Ngoko-Krama sebagai Representasi Hubungan Kekuasaan}

Pada masa sekarang, tingkat tutur bahasa Jawa itu berkembang ke arah seperti awal mula timbulnya, yaitu ngoko dan krama. Sampai sekarang ngoko dan krama masih mempertahankan fungsinya, yaitu (i) sebagai norma pergaulan masyarakat, (ii) sebagai tata unggah-ungguh, (iii) untuk menyatakan rasa hormat dan keakraban, (iv) dan sebagai pengatur jarak sosial (social distance), sebagaimana dijelaskan telah dijelaskan oleh Moedjanto (1987: 42).

Di antara keempat fungsi tersebut, fungsi keempatlah, yaitu sebagai pengatur jarak sosial, yang berkaitan dengan tingkat tutur sebagai representasi kekuasaan. Tingkat tutur sebagai represenstasi kekuasaan terwujud dalam tindak tutur. Dalam hal ini tindak tutur merupakan tindakan individual dan tindakan sosial. Sebagai tindakan individual, tindak tutur merupakan pengungkapan maksud ke dalam bahasa. Sebagai tindakan sosial, tindak tutur merupakan tindakan komunikatif, yaitu perbuatan penutur menjalin komunikasi dengan mitra tutur. Selain itu, tindak tutur juga merupakan perbuatan mitra bicara memosisikan diri dalam hubungan sosial dengan mitra tutur, apakah setara, lebih tinggi, atau lebih rendah. Pemosisian diri penutur, apakah setara, lebih tinggi, dan lebih rendah. Pemosisian diri penutur tersebut akan mewujudkan jenis-jenis komunikasi, yaitu (i) "komunikasi mendatar", "komunikasi menurun", dan (iii) "komunikasi mendaki" (Aslinda, 2007: 37-65) atau komunikasi menaik. Komunikasi mendatar terjadi bila penutur memosisikan diri dalam status sosial yang setara dengan mitra tutur. Komunikasi menurun terjadi jika penutur memosisikan diri dalam status sosial yang lebih tinggi daripada mitra tutur. Komunikasi mendaki terjadi apabila penutur memosisikan diri dalam status sosial yang lebih rendah daripada mitra tutur.

Terkait dengan relasi kekuasaan, komunikasi mendatar mencerminkan relasi dominatif yang relatif lebih rendah daripada komunikasi menurun dan mendaki. Komunikasi menurun dan mendaki menceminkan relasi dominatif yang tinggi antara penutur dengan mitra tutur, yaitu dalam komunikasi menurun, penutur mendominasi mitra tutur dan dalam komunikasi menaik, penutur didominasi oleh mitra tutur.

Dalam komunikasi mendatar, baik penutur maupun mitra tutur bisa sama-sama menggunakan ngoko atau sama-sama memakai krama. Faktor yang memengaruhi 
penutur dan mitra tutur yang sama-sama memakai tuturan ngoko atau tuturan krama adalah keakraban. Penutur dan mitra tutur yang memiliki hubungan yang akrab, sudah saling kenal cukup lama, dan hubungannya setara, misalnya tetangga, teman sekelas, teman ronda, dan sebagainya cenderung menggunakan tuturan ngoko dalam berkomunikasi.
(1) Teman A

Teman B
: Sesuk aku diampiri ya nek mangkat sekolah.Kowe tak tunggu neng arep ngomahku.

'Besok saya diampiri ya jika berangkat ke sekolah. Kamu saya tunggu di depan rumahku.'

: Ya, sesuk aku mampir neng omahmu jam pitu.

'Ya, besuk saya singgah di rumahmu jam tujuh.'

(2) Penumpang A : Ibu badhe tindak pundi?

'Ibu akan pergi ke mana?'

Penumpang B : Kulo badhe dateng Surabaya, Bu.

'Saya akan pergi ke Surabaya, Bu.'

Pada contoh (1) teman A dan B merupakan teman sekelas sehingga dalam berkomunikasi sama-sama menggunakan tuturan ngoko. Pada contoh (2) penumpang A dan penumpang $B$ belum saling mengenal duduk berdekatan ketika sama-sama sebagai penumpang kereta api Yogyakarta-Surabaya. Oleh karena belum saling mengenal, dalam berkomunikasi penumpang A dan penumpang B sama-sama menggunakan tuturan krama.

Baik tuturan ngoko maupun krama digunakan dalam komunikasi mendatar. Perbedaannya, selain dipakai dalam komunikasi mendatar, tuturan ngoko juga digunakan untuk komunikasi menurun, sedangkan tuturan krama juga dipakai dalam komunikasi mendaki. Dalam komunikasi menurun, penutur yang yang status sosialnya lebih tinggi menggunakan tuturan ngoko kepada mitra tutur yang status sosialnya lebih rendah. Dalam komunikasi mendaki, penutur yang status sosialnya lebih rendah memakai tuturan krama kepada mitra tutur yang status sosialnya lebih tinggi. Penggunaan tuturan ngoko-krama dalam komunikasi mendaki dan menurun merepresentasikan hubungan kekuasaan (i) orang yang berusia tua-muda, (ii) orang yang memiliki hubungan kekerabatan tua-muda, (iii) pemerintahrakyat, (iv) atasan-bawahan, (v) majikanburuh, (vi) suami-istri.

\subsubsection{Tuturan Ngoko-Krama sebagai Representasi Hubungan Kekuasaan Usia Tua-Muda}

Hubungan tua-muda ditentukan oleh tiga faktor, yaitu (i) usia, (ii) hubungan kekerabatan, dan (iii) senioritas. Terkait dengan faktor usia, tua berkenaan umur yang lebih banyak, sedangkan muda berkaitan dengan umur yang lebih sedikit. Dalam masyarakat Jawa, orang yang lebih tua memiliki dominasi lebih kuat daripada yang lebih orang yang lebih muda. Orang yang sudah tua disebut pini sepuh atau kasepuhan 'tetua' dipandang memiliki kekuasaan yang lebih dibandingkan dengan orang yang masih muda. Para pini sepuh atau kasepuhan, apalagi pini sepuh yang hidupnya dapat diteladani, sangat dihormati oleh orang muda. Pini sepuh adalah orang yang lebih lama hidup dan 
karena itu memiliki lebih banyak pengalaman hidup dan dianggap lebih bijaksana. Para pini sepuh atau kasepuhan memiliki hak menasihati orang muda. Apabila terjadi sebaliknya, yaitu orang muda menasihati pini sepuh atau kasepuhan, maka akan dikatakan sebagai orang yang ntranyak dan akibatnya orang muda itu bisa kuwalat.

Dalam komunikasi publik, pini sepuh memperoleh penghormatan yang lebih sehingga disapa pertama kali oleh penutur dengan tuturan para pini sepuh ingkang dahat kinormatan 'para tetua yang pantas memperoleh penghormatan'. Dalam komunikasi antarpribadi, penutur yang lebih tua menggunakan ngoko kepada mitra tutur yang lebih muda, sedangkan penutur yang lebih muda memakai krama kepada mitra tutur yang lebih tua. Berikut ini dipaparkan contohnya.

$$
\begin{aligned}
& \text { Seorang bapak : Esuk-esuk ngene kowe arep menyang ngendi? } \\
& \text { 'Pagi-pagi bergini kamu akan pergi ke mana?' } \\
& \text { Seorang pemuda : Kula badhe dateng peken, Pak. } \\
& \text { 'Saya akan pergi ke pasar, Pak.' }
\end{aligned}
$$

Pada contoh (3) penutur, yaitu seorang bapak yang usianya lebih tua menggunakan tuturan ngoko daripada mitra tutur, yaitu seorang pemuda yang usianya lebih muda, sedangkan seorang pemuda menggunakan tuturan krama kepada seorang bapak. Pada contoh (4) penutur, yaitu seorang ibu yang usianya lebih tua, memakai tuturan ngoko kepada mitra tutur yang usianya lebih muda, yaitu seorang gadis, sedangkan seorang gadis menggunakan tuturan kormo kepada seorang ibu.

\subsubsection{Tuturan Ngoko-Krama sebagai Representasi Hubungan Kekuasaan Kekerabatan Tua-Muda}

Tua-muda juga berkaitan dengan hubungan kekerabatan. Dalam masyarakat
Jawa, tua-muda menjadi pembeda hubungan kekerabatan, misalnya orangtua-anak, adikkakak, nenek-cucu, paklik-keponakan, bulikkeponakan, pakde-keponakan, budekeponakan, dan sebagainya. Dalam hubungan kekerabatan di masyarakat Jawa dikenal adanya kaprenah tua 'berkedudukan lebih tua' dan kaprenah enom 'berkedudukan lebih muda'. Orang yang lebih muda berkewajiban menghormati orang yang lebih tua. Dalam komunikasi verbal, saudara tua biasa menggunakan tuturan ngoko kepada orang yang lebih muda, sedangkan orang yang lebih muda memakai tuturan krama kepada orang yang lebih tua. Berikut ini dikemukakan contohnya.
(5) Nenek

Cucu
: Wis mbengi kowe durung turu. 'Sudah malam kamu belum tidur'

: Dereng Mbah. Kula dereng ngantuk. 
'Belum Nek. Saya belum mengantuk'

(6) Ayah

Anak

(7) Paman

Keponakan
: Le, endang mangkat sekolah. Iki wis awan mudhak telat.

'Nak, segera berangkat ke sekolah. Ini sudah siang supaya tidak terlambat'

: Nggih Pak. Kulo enggal badhe mangkat sekolah.

'Ya Pak. Saya segera akan berangkat ke sekolah'

: Sarno, tulung aku terno nang kantor pos.

'Sarno, tolong saya diantarkan ke kantor pos'.

: Nggih Pakdhe, sekedhap malih Pakdhe kulo dherekaken.

'Ya Pakde, sebentar lagi Pakde saya antar'
Tindak tutur (5) dilakukan oleh seorang nenek kepada cucunya dan sebaliknya. Oleh sebab nenek memiliki hubungan kekerabatan yang lebih tua, sang nenek menggunakan tuturan ngoko kepada cucunya, sedangkan cucunya bertutur krama kepada nenek. Pada contoh (6) terdapat tindak tutur yang dilakukan oleh ayah kepada anaknya dan sebaliknya. Ayah memakai tuturan ngoko dalam berkomunikasi dengan anaknya, sedangkan anaknya bertuturan krama kepada ayahnya. Dalam data (7), paman menggunakan tuturan ngoko kepada keponakannya, sedangkan keponakan menggunakan tuturan krama.

\subsubsection{Tuturan Ngoko-Krama sebagai Representasi Hubungan Kekuasaan Pemerintah-Rakyat}

Pemerintah yang dimaksud pada zaman kerajaan adalah raja, keluarga raja, dan pejabat kerajaan. Raja, keluarga raja, dan pejabat kerajaan biasanya menggunakan tuturan ngoko apabila berkomunikasi dengan rakyat. Rakyat memakai tuturan krama bila berkomunikasi dengan raja, keluarga raja, atau pejabat kerajaan.

Pada zaman sekarang, yang disebut pemerintah adalah pejabat dan pegawai di kantor pemerintahan, misalnya dukuh, lurah atau kepala desa, camat, bupati, dan sebagainya. Di masyarakat Jawa, masih sering terjadi komunikasi antara pejabat pemerintah dan rakyat berlangsung dalam bahasa Jawa. Bila demikian, masih sering terjadi pejabat pemerintah menggunakan tuturan ngoko kepada rakyat, sedangkan rakyat memakai tuturan krama kepada pejabat pemerintah. Pada masa sekarang pejabat pemerintah yang lebih dekat dan lebih sering berkomunikasi dengan rakyat adalah pejabat dan perangkat desa, termasuk dukuh. Berikut ini dikemukakan contohnya.

$$
\begin{aligned}
& \text { Pak Dukuh A : Pak, sesuk kanca-kanca diajak kerja bakti ndandani dalam sing } \\
& \text { rusak merga kejugrugan lemah kae. } \\
& \text { 'Pak, besok teman-teman diajak bekerja bakti memperbaiki } \\
& \text { jalan yang rusak karena kelongsoran tanah di sana itu' } \\
& \text { Warga : Nggih Pak Dukuh, sedaya warga badhe kulo caosi priksa supados } \\
& \text { Pedukuhan A benjang sami nderek kerja bakti } \\
& \text { 'Baik Pak Dukuh, semua warga akan saya minta supaya } \\
& \text { besuk ikut bekerja bakti' }
\end{aligned}
$$




$$
\begin{aligned}
& \text { Kepala Desa A : Esuk-esuk kowe mara mrene, arep butuh apa? } \\
& \text { 'Pagi-pagi kamu datang ke sini akan perlu apa?' } \\
& \text { Warga Desa A : Nyuwun pangapunten Pak Lurah, taksik enjang kulo sowan } \\
& \text { Bapak badhe nyuwun tapak asta. } \\
& \text { 'Mohon maaf Pak Lurah, masih pagi begini saya datang } \\
& \text { kepada Bapak untuk minta tanda tangan' }
\end{aligned}
$$

Pada contoh (8) Pak Dukuh A memakai tuturan ngoko dalam berkomunikasi dengan warga Pedukuhan A, sedangkan warga Pedukuhan A menggunakan tuturan krama dalam berbicara dengan Pak Dukuh A. Dalam contoh (9) Kepala Desa A yang disapa Pak Lurah berbicara dengan tuturan ngoko kepada warga desa A, sedangkan warga Desa A memakai tuturan krama pada saat berkomunikasi dengan Kepala Desa A.

\subsubsection{Tuturan Ngoko-Krama sebagai Representasi Hubungan Kekuasaan Majikan-Buruh}

Majikan adalah pemilik usaha, sedangkan buruh adalah pegawainya. Di masyarakat desa Jawa, majikan bisa pemilik tanah, sedangkan buruh adalah penggarap tanah majikan. Majikan juga bisa pemilik usaha, misalnya usaha penggilingan gabah, usaha pembuatan tahu, dan usaha dagang lain. Buruh adalah pegawai dari pemilik usaha. Dalam keluarga yang memiliki pembantu rumah tangga atau pramuwisma, keluarga itu juga merupakan majikan, sedangkan pramuwisma adalah buruh. Tentu saja majikan lebih berkuasa daripada buruh. Oleh karena itu, dalam berkomunikasi dalam bahasa Jawa, majikan lazim berbahasa ngoko kepada buruhnya, sedangkan buruh menggunakan bahasa krama kepada majikannya. Berikut ini contoh dialog majikan buruh.

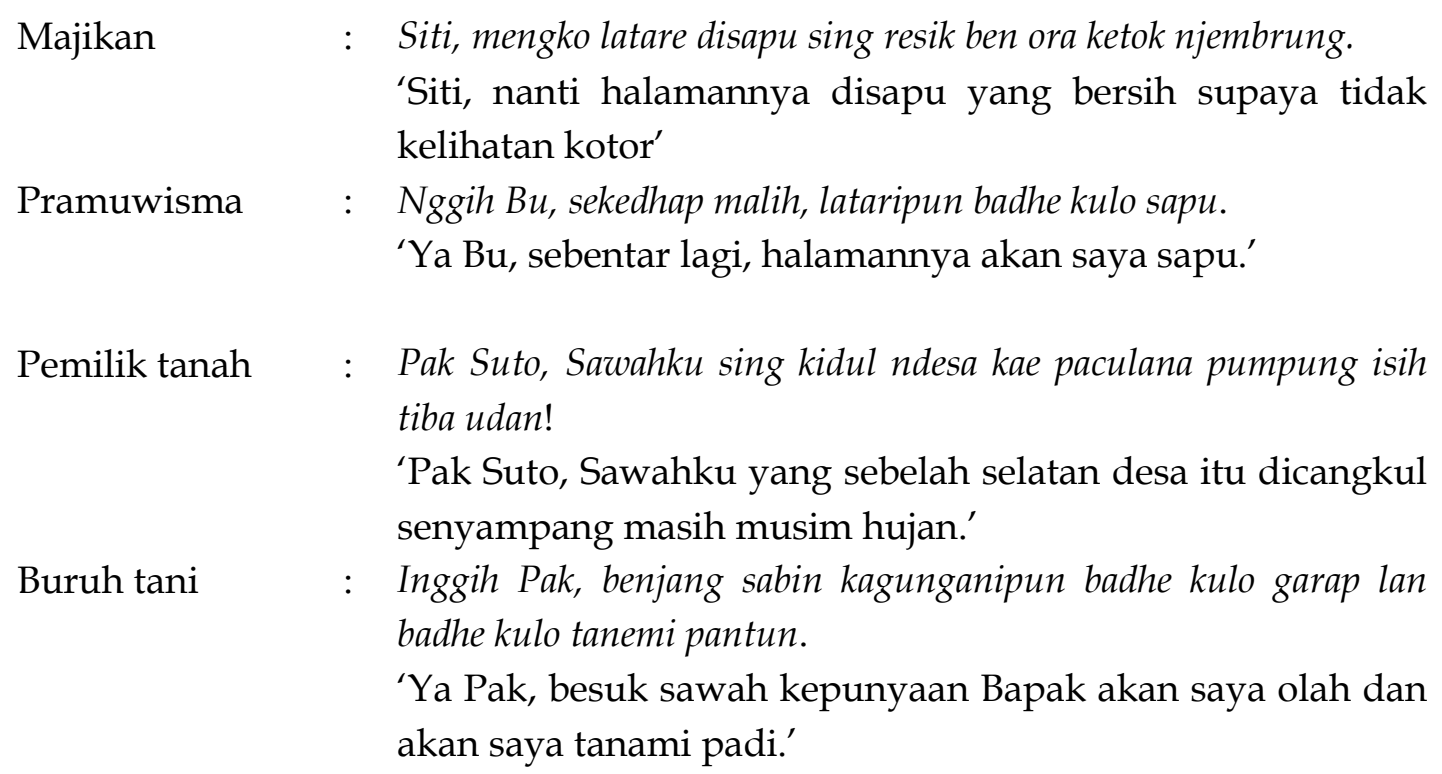

Pada contoh (10) tampak bahwa majikan

Demikian pula, pada contoh (11) pemiliki menggunakan tuturan ngoko kepad pramuwisma, sedangkan pramuwisma tanah berbahasa ngoko kepada buruh tani, memakai tuturan krama kepada majikannya. kepada pemilik tanah sebagai majikannya. 
4.4.5. Tuturan Ngoko-Krama sebagai bupati dan sekretaris daerah, kepala dinas; Representasi Hubungan Kekuasaan ketua organisasi memiliki bawahan wakil Atasan-Bawahan

Istilah atasan bisa menunjuk pemimpin, ketua, sekretaris, bendahara, dan anggota. Tidak jarang bahasa Jawa masih digunakan untuk berkomunikasi di instansi atau kepala, ketua dalam instansi pemerintah, instansi swasta, atau organisasi. Istilah bawahan bersangkutan dengan anak buah atau anggota. Contohnya adalah kepala sekolah merupakan atasan dari para guru; kepala desa memiliki bawahan pamong desa dan dukuh; bupati memiliki bawahan wakil organisasi. Dalam komunikasi tersebut, atasan cenderung menggunakan tuturan ngoko kepada bawahannya, sedangkan bawahan berbahasa krama kepada atasannya. Berikut ini diberikan contoh komnukasi verbal antara atasan dan bawahan.

$\begin{aligned} \text { Kepada Sekolah : } & \text { Pak, murid-murid sing melu lomba cerdas cermat tulung } \\ & \text { dibimbing ya. } \\ & \text { 'Pak, murid-murid yang akan ikut lomba cerdas cermat } \\ & \text { tolong dibimbing ya.' } \\ \text { Guru } & \text { Nggih Bu, pendhak dinten Setu badhe kulo adani latihan cerdas } \\ & \text { cermat! } \\ & \text { 'Baik Bu, setiap hari Sabtu akan diadakan pelatihan cerdas } \\ & \text { cermat.' }\end{aligned}$

(13) Kepala Desa : Sesuk Pak carik makili aku rapat neng kecamatan ya. 'Besok Pak Carik mewakili saya rapat di kecamatan ya.'

Pak Carik : Nggih Pak Lurah, benjang kulo mboten wonten padamelan. 'Ya Pak Lurah, besok saya tidak ada pekerjaan.'

Contoh (12) merupakan dialog kepala sekolah sebagai atasan dengan guru sebagai bawahan. Pada contoh (12) kepala sekolah memakai tuturan ngoko kepada guru, sedangkan guru menggunakan bahasa kormo kepada kepala sekolah. Contoh (13) adalah dialog kepala desa dengan pak carik. Dalam dialog tersebut kepala desa berbahasa ngoko kepada pak carik, sedangkan pak carik memakai tuturan kormo kepada kepala desa.

\subsubsection{Tuturan Ngoko-Krama sebagai Representasi Hubungan Kekuasaan Suami-Istri}

Pada masa yang lalu, di masyarakat Jawa suami lebih dominan daripada istri. Istri itu kanca wingking 'teman yang ada di belakang suami'. Seiring dengan adanya gerakan kesetaraan antara laki-laki dan perempuan, sekarang hubungan suami-istri sudah cenderung setara. Meskipun demikian, sekarang masih ada juga anggota masyarakat yang memandang suami. Masih ada dalam masyarakat Jawa, dalam komunikasi suami menggunakan tuturan ngoko, sedangkan istri memakai bahasa kormo. Berikut ini dikemukakan contoh penggunaan tuturan ngoko-krama untuk merepresentasikan hubungan kekuasaan suami-istri. 
(14) Suami

Istri
: Bu, tulung omahe diresiki merga suk malem Minggu Legi omahe awake dhewe kenggonan kumpulan bapak-bapak RT.

‘Bu, tolong rumahnya dibersihkan sebab malam Minggu Legi rumah kita ketempatan pertemuan bapak-bapak RT.'

: Inggih Mas, griya badhe kulo resiki saderenge kangge kempalan. 'Ya Mas, rumah akan saya bersihkan sebelum dipakai untuk pertemuan.'

Data (14) menunjukkan bahwa suami menggunakan tuturan ngoko kepada istrinya, sedangkan istri memakai tuturan kormo kepada suaminya.

\section{KESIMPULAN}

Tingkat tutur yang pokok dalam bahasa Jawa adalah ngoko dan kormo. Tingkat tutur ngoko dan krama dalam bahasa Jawa dibedakan dari kosakatanya. Dalam bahasa Jawa terdapat kosakata ngoko dan kosakata kormo. Dalam penggunaannya, kosakata ngoko dan krama itu menimbulkan berbagai variasi tingkat tutur. Tingkat tutur bahasa Jawa menjadi bahasa ngoko, bahasa madya, dan bahasa krama. Kemudian bahasa ngoko dibagi lagi menjadi ngoko lugu, ngoko antya-basa, dan ngoko basa-antya. Bahasa ngoko ditandai dengan penggunaan kosakata ngoko dan imbuhan di-, -(n)e, dan -(k)ake. Kemudian ngoko lugu merupakan bahasa ngoko yang terdiri atas semua kosakata ngoko dan imbuhan ngoko. Ngoko antya-basa ditandai dengan penggunaan kosa kota ngoko yang dicampuri krama dan penggunaan imbuhan ngoko. Ngoko basa-antya terdiri atas kosakata ngoko dan krama serta imbuhan ngoko.

Bahasa krama memiliki variasi wredha krama, kramantara, dan mudha krama. Bahasa krama ditandai dengan kosakata krama dan imbuhan krama, yaitu dipun-, -(n)ipun, dan (k)aken. Wreda krama lazim digunakan untuk berkomunikasi antara orang muda (wreda) kepada orang muda. Dalam wreda krama digunakan kosakata krama dan imbuhan ngoko. Kramantara digunakan dalam komunikasi antara penutur dan mitra tutur yang status sosialnya sama (jabatan, pangkat, pendidikan, usia). Kramantara ditandai dengan penggunaan kosakata dan imbuhan krama. Mudha krama biasanya digunakan untuk berkomunikasi antara orang muda (mudha) dengan orang tua. Mudha krama ditandai dengan penggunaan kosakata krama (inggil) dan imbuhan krama.

Bahasa madya merupakan variasi tingkat tutur yang berada di antara ngoko dan krama. Bahasa madya memiliki variasi madya krama, madyantara, dan madya ngoko. Madya ngoko ditandai dengan pemakaian kosakata krama dan kosakata ngoko serta imbuhan ngoko. Madyantara merupakan variasi tingkat tutur bahasa Jawa yang ditandai dengan pemakaian kosakata krama dan imbuhan ngoko. Madya krama adalah variasi tingkat tutur bahasa Jawa yang ditandai penggunaan kosakata krama (inggil) dan imbuhan ngoko.

Dari uraian tersebut, dapat disebutkan ada sembilan variasi tingkat tutur dalam bahasa Jawa, yaitu ngoko lugu, antya-basa, basaantya, wredha krama, kramantara, mudha krama madya krama, madyantara, dan madya ngoko. Selain itu, ada pula peneliti bahasa Jawa yang menyebutkan ada tiga belas variasi tingkat tutur dalam bahasa Jawa, yaitu ngoko lugu, ngoko antya-basa, ngoko basa-antya, madya ngoko, madyantara, madya krama, mudha krama, kramantara, wredha krama, krama desa, krama inggil, basa kedhaton, dan basa kasar.

Dilihat dari sejarah pekerkemangannya, pada awalnya tingkat tutur dalam bahasa 
Jawa digunakan untuk merepresentasikan kekuasaan politik. Tingkat tutur ngoko dan krama mulai berkembang pada zaman Kerajaan Mataram, yaitu pada tahun 1600-an, pada pemerintahan Sultan Agung. Sebelum kerajaan Mataram, tidak dikenal adanya tingkat tutur ngoko dan krama. Pada mulanya tingkat ngoko dan krama digunakan untuk merepresentasikan hubungan kekuasaan politik. Pengembangan tingkat tutur ngoko dan krama digunakan untuk memperkokoh kedudukan dinasti Mataram sebagai dinasti penguasa di Jawa. Tingkat tutur ngoko dan krama dipakai untuk menciptakan jarak sosial antara kelompok penguasa (raja) dengan kelompok sosial yang lebih rendah (rakyat). Tuturan ngoko digunakan oleh kelompok penguasa untuk memerintah rakyat, sedangkan tuturan krama digunakan oleh rakyat untuk menghormati kelompok penguasa.

Pada perkembangan selanjutnya sampai sekarang, tingkat tutur ngoko dan krama digunakan untuk merepresentasikan hubungan kekuasaan pesonal. Tuturan ngoko dipakai dalam berkomunikasi menurun, yaitu komunikasi antara penutur yang sosialnya tinggi kepada mitra tutur yang status sosialnya lebih rendah. Tingkat tutur krama digunakan dalam berkomunikasi menaik atau mendaki, yaitu komunukasi antara penutur yang satatus sosialnya rendah kepada mitra tutur yang status sosialnya tinggi, yaitu untuk menghormati mitra tutur yang status sosialnya lebih tinggi. Penggunaan tuturan kormo dalam komunikasi menurun dan mendaki merepresentasikan hubungan kekuasaan (1) orang yang berusia tua-muda, (2) orang yang memiliki hubungan kekerabatan tua-muda, (3) pemerintah-rakyat, (4) atasan-bawahan, (5) majikan-buruh, (6) suami-istri.

Akibat perkembangan demokrasi, terjadilah proses defeodalisasi. Defeodalisasi ini lambat laun menyebabkan penggunaan ngoko-krama menjadi lebih menonjol sebagai sarana sopan santun daripada sarana untuk mewujudkan relasi kekuasaan.

\section{DAFTAR PUSTAKA}

Anderson, Benedict R.OG. 1990. Langauge and Power: Exploring Political Cultures in Indonesia. Ithaca and London: Cornell University Press.

Baryadi, I. Praptomo. 2012. Bahasa, Kekuasaan, dan Kekerasan. Yogyakarta: Universitas Sanata Dharma.

Driyarkara, N. 1980. Driyarkara tentang Pendidikan. Yogyakarta: Penerbit Kanisius.

Fairclough, Norman. 1995. Language and Power. London and New York: Longman Group UK Limited.

Geertz, Clifford. 1989. Abangan, Santri, Priyayi dalam Masyarakat Jawa. Cetakan Ke-3. Diterjemahkan oleh Aswab Mahasin. Jakarta: Pustaka Jaya.

Harjawiyana, Haryana dan Th. Supriya. 2001.

Kamus Unggah-Ungguh Basa Jawa. Yogyakarta: Penerbit Kanisius.

Moedjanto, G. 1987. Konsep Kekuasaan Jawa:

Penerapannya oleh Raja-Raja Mataram. Yogyakarta: Penerbit Kanisius.

Peirce, Charles. 1985. "Logic as Semiotic: The Theory of Signs." Dalam Robert E. Innis (ed.). Semiotics: An Itroductory Anthology. Bloomington: Indiana University Press. Hlm. 1-23.

Poedjosoedarmo, Soepomo. 1979. Tingkat Tutur dalam Bahasa Jawa. Jakarta: Pusat Pembinaan dan Pengembangan Bahasa. Sasangka, Sry Satriya Tjatur Wisnu. 1994. Tingkat Tutur Bahasa Jawa Berdasarkan Leksikon Pembentuknya. Surabaya: Penerbit Yayasan "Djojo Bojo".

Sudaryanto. 2015. Metode dan Aneka Teknik Analisis Data: Pengantar Penelitian 
Wahana Kebudayaan secara Linguistis. Wareing, Shan. 2007. "Apa Bahasa Itu dan Yogyakarta: Sanata Dharma University Press.

Suwadji. 2013. Ngoko lan Krama. Yogyakarta: Yayasan Pustaka Nusatama.

Titscher, Stefan dkk. 2009. Metode Analisis Teks dan Wacana. Diterjemahkan oleh Gazali dkk. dari judul asli Methods of Text and Disourse Analysis. Yogyakarta: Penerbit Pustaka Pelajar.

Apa Peranannya?". Dalam Linda Thomas dan Shan Wreing (Ed.). Bahasa, Masyarakat, dan Kekuasaan. Diterjemahkan oleh Sunoto dkk. dari Language, Society, and Power. Yogyakarta: Pustaka Pelajar, Halaman 1-26.

Wodak, Ruth. 1996. Disorders of Discourse. Singapore: Longman Singapore Publisher (Pte) Ltd. 